The congress of 1963 was held at the University of Saskatchewan from September 1 to 4 . Details of the activities are to be found on the following pages:

Programme .......................... 160

Invited lectures ................... 161

Contributed papers ................. 161

Symposium on graduate work ............ 161

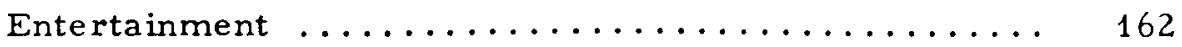

Business Meeting.................... 163

List of those attending the congress .......... 165

Acknowledgement .................... 167

Symposium on Graduate Work ............ 175

Abstracts of Contributed Papers ............. 185

A non-inductive definition for a regular polytope, H. S. M. Coxeter ............. 185

An algorithmic solution to a word problem in group theory, N.S. Mendelsohn ......... 186

A generalization of Taylor series and

Newton interpolation of entire functions,

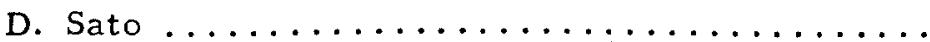

Regular polygons over Galois fields,

B. M. Puttaswamaiah and G. de B. Robinson .... 188

Boolean geometry of p-rings, R. A. Melter .... 189

Invited Lectures....................... 191

Equal sums of like powers, E. M. Wright ..... 193

The algebra of dimension-linking ope rators,

R. H. Bruck .................... 203

Mathematics in Poland today, K. Kuratowski... 223

The training of secondary school teachers in the

Federal Republic of Germany, G. Pickert ..... 233 
Sunday, September 1
2:00 p. m.
Registration
$6: 30$ p.m.
Meeting of the Executive Committee
9:00 p. m.
Reception

Monday, September 2

$\begin{aligned} \text { 9:00 a.m. } & \begin{array}{l}\text { Business Meeting of the Canadian } \\ \text { Mathematical Congress }\end{array} \\ \text { 11:00 a.m. } & \text { Lecture, E. M. Wright } \\ \text { 2:00 p.m. } & \text { Meeting of the Council } \\ \text { 8:00 p. m. } & \text { Lecture, R. H. Bruck }\end{aligned}$

Tuesday, September 3
9:30 a.m.
Lecture, K. Kuratowski
2:00 p.m.
Symposium on Graduate Work
8:00 p. m.
Lecture, G. Pickert

Wednesday, September 4
9:00 a.m.
Contributed Papers
2:00 p. m.
Business Meeting of the Canadian
Mathematical Congress
6:30 p. m.
Dinner offered by the Province of Saskatchewan 
E. M. Wright, University of Aberdeen, Scotland Equal sums of like powers

R. H. Bruck, University of Wisconsin, Madison The algebra of dimension-linking operators

K. Kuratowski, University of Warsaw, Poland Mathematics in Poland today

G. Pickert, University of Giessen, Germany The training of secondary school teachers in the Federal Republic of Germany

\section{Contributed papers}

H.S.M. Coxeter, University of Toronto A non-inductive definition for a regular polytope

N.S. Mendelsohn, University of Manitoba

An algorithmic solution to a word problem in group theory

D. Sato, University of Saskatchewan, Regina

Newton interpolation of entire functions

B. M. Puttaswamaiah and

G. de B. Robinson, University of Toronto Regular polygons over Galois fields

R. A. Melter, University of Rhode Island Boolean geometry of $\mathrm{p}$-rings

\section{Symposium on graduate work}

R. D. James (presiding), University of British Columbia

M. Wyman, University of Alberta

H. S. M. Coxeter, University of Toronto

R. L. Jeffery, Acadia University

F. A. Sherk, University of Toronto 
Members of the Congress and their wives were entertained at a reception by the University of Saskatchewan at which the guests were greeted by President Spinks and Mrs. Spinks in the Memorial Union Building, on Sunday evening, September 1.

On the final day, September 4, all participants and their wives were guests of the Province of Saskatchewan at a banquet held in the Bessborough Hotel. The Honourable Olaf A. Turnbull, Minister of Education, was chairman and welcomed the delegates on behalf of the province of Saskatchewan. Professor G. Pickert expressed the pleasure of the visiting lecturers. Professor R. D. James delivered an address as retiring president of the Congress. 
A meeting of the Congress was held in which reports and other business was transacted.

The list of elected and permanent officers is as follows:

Past President

President

Vice-Presidents

Executive Director

Treasurer

English Secretary

French Secretary

Council Members:

From the West
R. D. James, University of British Columbia Max Wyman, University of Alberta

H.S. M. Coxeter, University of Toronto M. L'Abbé, University of Montreal

N.S. Mendelsohn, University of Manitoba

L. F.S. Ritcey, McGill University

W. L. G. Williams (retired), McGill University

R. E. O'Connor, S. J., Loyola College

J. M. A. Maranda, University of Montreal

A. L. Dulmage, University of Manitoba

A. P. Guinand, University of Saskatchewan

T.E. Hull, University of British Columbia

S. A. Jennings, University of British Columbia

A. E. Livingston, University of Alberta

L. Lorch, University of Alberta

D. Murdoch, University of British Columbia

J. E. L. Peck, University of Alberta at Calgary

From Ontario and

Quebec

B. Banaschewski, McMaster University

R. H. Cole, University of Western Ontario

A.J. Coleman, Queen's University

A. Daigneault, University of Montreal

G. F. D. Duff, University of Toronto

J. Lambek, McGill University

F. Lemay, Laval University

P. G. Rooney, University of Toronto

E. M. Rosenthall, McGill University

H. Schwerdtfeger, McGill University

D. B. Sumner, McMaster University

W. T. Tutte, University of Waterloo 
From the Atlantic

Provinces

W. J. Blundon, Memorial University of Newfoundland

K. D. C. Haley, Acadia University

R. L. Rosenberg, University of New Brunswick

A. J, Tingley, DaIhousie University

Editor-in-Chief .... Canadian Journal of Mathematics P. Scherk, University of Toronto

Managing Editor.... Canadian Journal of Mathematics

G. de B. Robinson, University of Toronto

Editor-in-Chief .... Canadian Mathematical Bulletin W. Moser, University of Manitoba

Managing Editor.... Canadian Mathematical Bulletin F.A. Sherk, University of Toronto

Director......... Summer Research Institute R. L. Jeffery, Acadia University 
Artiaga, L.

Birkinshaw, E. A.

Blum, E.

Blum, R.

Bode, Miss Anne

Brown, W. G.

Bush, G. C.

Chakravartty, I. C.

Cole, R. H.

Coleman, A.J.

Coxeter, H.S.M.

Crosby, D. R.

Cuttle, P.

Cuttle, Yvonne

Ellis, H.W.

Faught, D.

Fujiwara, T.

Garner, C. W. L.

Guinand, A. P.

Haley, K. D. C.

Hayes, J.C.

Holland, A.S.B.

Hrycay, R.

Herzberg, A.M.

James, R. D.

Jeffery, R. L.

Jonsson, W. J.

Kalbfleisch, J.

Keeping, A. J.

Kinoshitá, S.

Kuratowski, K.
University of Windsor, Windsor, Ontario

Brandon College, Brandon, Manitoba Acadia University, Wolfville, N.S.

University of Saskatchewan, Saskatoon

University of Western Ontario, London

University of British Columbia, Vancouver

Queen's University, Kingston, Ontario

University of Saskatchewan, Saskatoon

University of Western Ontario, London

Queen's University, Kingston, Ontario

University of Toronto, Toronto, Ontario

University of Alberta, Emonton, Alberta

University of Saskatchewan, Saskatoon

University of Saskatchewan, Saskatoon

Queen's University, Kingston, Ontario

University of Windsor, Windsor, Ontario University of Alberta, Edmonton, Alberta

University of Toronto, Toronto, Ontario University of Saskatchewan, Saskatoon

Acadia University, Wolfville, N.S.

Colle ge Militaire Royal de St. Jean, P. Q.

University of Alberta, Calgary, Alberta

University of Saskatchewan, Saskatoon

University of Saskatchewan, Saskatoon

University of British Columbia, Vancouver Acadia University, Wolfville, N.S.

University of Manitoba, Winnipeg, Manitoba

Apt.16A, 190 Lester St., Waterloo, Ontario University of Alberta, Calgary, Alberta University of Saskatcliewan, Saskatoon University of Warsaw, Warsaw, Poland 
L'Abbe, M.

Lancaster, $P$.

Lane, $N$. D.

Lorch, Lee

Malik, M. A.

Melter, R. A.

MendeIsohn, N.S.

Miller, C.E.

Moser, L.

Moser, W.

Nasim, C.

Noonan, B.

O'Connor, R. E.

Pearson, T.L.

Peck, J.E. L.

Ritcey, L. F.S.

Robinson, G. de B.

Rosenberg, R. L.

Rosenthall, E.

Sato, D.

Saucier, J.

Scherk, P.

Seiden, Esther

Sherk, F.A.

Shklov, N.

Snow, D. $O$.

Stanton, R. G.

Thomas, G.

Tingley, A.J.

Toews, K. G.

Tutte, W. T.

Upadhyay, $M$.

Willett, D. W.

Williams, W. L. G.

Zeiler, F.
University of Montreal, Montreal, P. Q.

University of Alberta, Calgary, Alberta

McMaster University, Hamilton, Ontario

University of Alberta, Edmonton, Alberta

University of Montreal, MontreaI, P.Q.

University of Rhode IsIand, Kingston, R. I.

University of Manitoba, Winnipeg, Manitoba

University of Saskatchewan, Saskatoon

University of Alberta, CaIgary, Alberta

University of Manitoba, Winnipeg, Manitoba '

University of Saskatchewan, Saskatoon

University of Manitoba, Winnipeg, Manitoba

Loyola College, Montreal, P.Q.

University of Saskatchewan, Saskatoon University of Albcrta, CaIgary, Alberta

Canadian Mathematical Congress

University of Toronto, Toronto, Ontario University of New Brunswick, Fredericton McGill University, Montreal, P.Q.

University of Saskatchewan, Regina University of Toronto, Toronto, Ontario University of Toronto, Toronto, Ontario Michigan State University, East Lansing University of Toronto, Toronto, Ontario University of Saskatchewan, Saskatoon Acadia University, Wolfville, N.S. University of Waterloo, Waterloo, Ontario

University of Saskatchewan, Saskatoon

Dalhousie University, Halifax, N.S.

University of Saskatchewan, Regina

University of WaterIoo, Waterloo, Ontario

University of Saskatchewan, Saskatoon

University of Alberta, Calgary

Canadian Mathematical Congress

University of Manitoba, Winnipeg, Manitoba 
As Executive Director of the Canadian Mathematical Congress, I take pleasure in here recording, on behalf of the Congress, the names of the public bodies and companies which contributed to our general fund during the year 1963, and thus gave their support to our various activities.

The present list includes not only the National Research Council and five provinces but also almost all of the Canadian life insurance companies and chartered banks, and a large number of industrial and engineering companies.

Sustaining Members

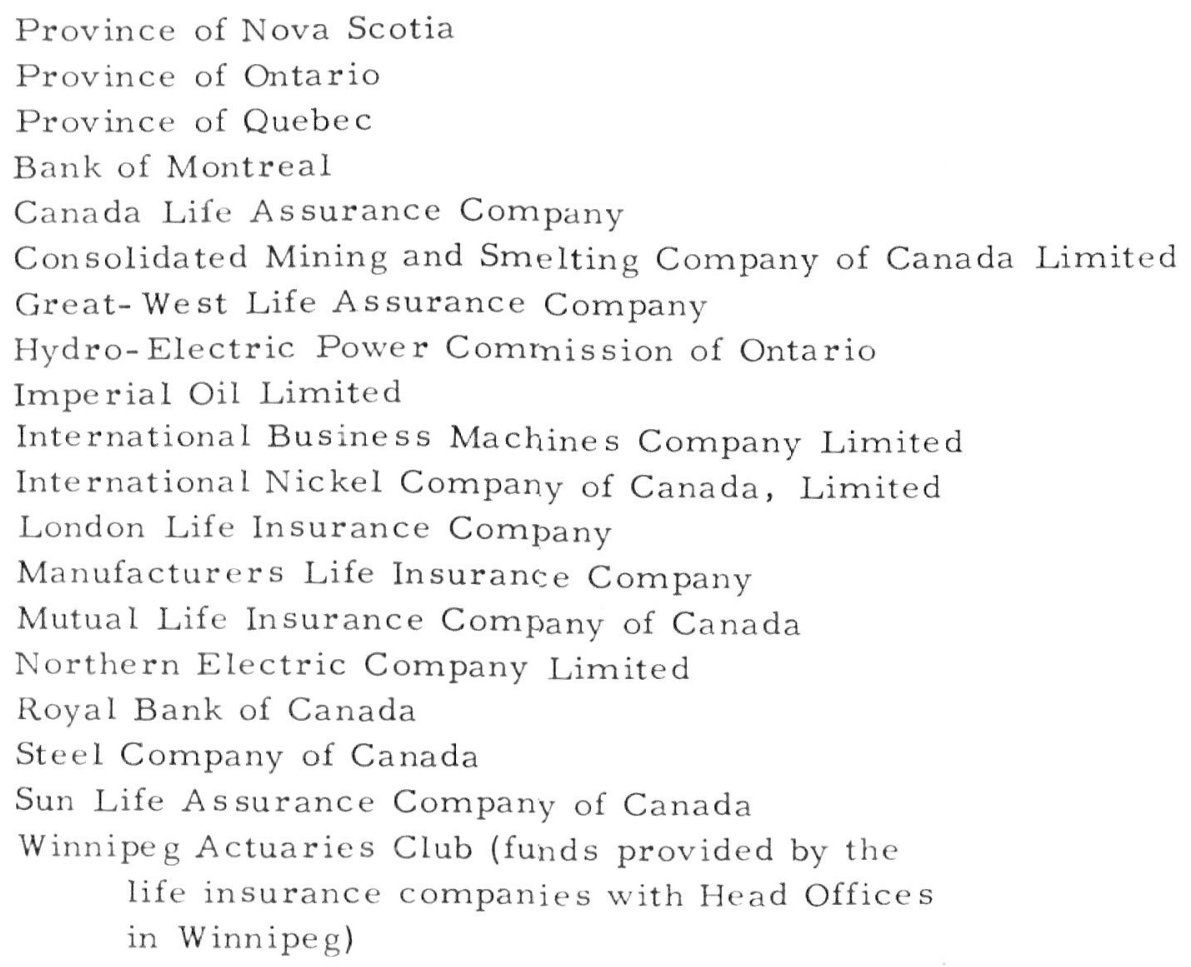


National Research Council

Province of New Brunswick

Province of Saskatchewan

Abitibi Power and Paper Company, Limited

Algoma Steel Corporation, Limited

Alliance Compagnie Mutuelle d'Assurance-Vie

Allied Chemical Canada, Limited

Aluminum Company of Canada, Limited

Ames, A. E. and Company, Limited

Anaconda American Brass, Limited

Anglo-Canadian Pulp and Paper Mills, Limited

Anthes-Imperial Company, Limited, St. Catharines

Asbestos Corporation Limited

L'Assurance-Vie Desjardins

Automatic Electric (Canada) Limited

Babcock-Wilcox and Goldie-McCulloch, Limited, Galt

Bank of Nova Scotia

Banque Canadienne Nationale

S. Belzberg Enterprises, Edmonton

Beneficial Finance Company of Canada

Henry Birks and Sons (Montreal) Limited

Blackwood Hodge Quebec, Limited

British American Oil Company, Limited

British Columbia Forest Products, Limited, Vancouver

British Columbia Telephone Company

Brock Engineering Manufacturing Co. Ltd.

Bruck Mills Limited, Montreal

Buckwold's Limited, Saskatoon

Burans and Company, Limited

Burns Bros. and Denton, Limited

Calgary Power, Limited

California Standard Company, Calgary

Canada Cement Company, Limited

Canada Iron Foundries, Limited

Canada Packers Foundation

Canada Safeway, Limited

Canada Starch Company, Limited

Canada Steamship Lines, Limited

Canada Wire and Cable Company, Limited

Canadian Bank Note Company, Limited

Canadian Bedding Company, Limited, Edmonton 
Canadian Blower and Forge Company, Limited, Kitchener

Canadian Comstock Company Limited

Canadian Fishing Company Ltd., Vancouver

Canadian Forest Products, Limited, Vancouver

Canadian General Electric Company, Limited

Canadian General Tower, Limited

Canadian Imperial Bank of Commerce

Canadian Industries Limited

Canadian Ingersoll-Rand Company, Limited

Canadian Marconi Company

Canadian Pacific Railway Company

Canadian Premier Life Insurance Company

Canadian Refractories Limited

Canadian Salt Company Limited

Canadian Society of Exploration Geophysicists

Canadian Sportswear Limited, Winnipeg

Canadian Superior Oil Limited

Canadian Utilities Limited, Edmonton

Canadian Wallpaper Manufacturers, Limited

Canadian Western Natural Gas Company Limited, Edmonton

Canadian Westinghouse Company, Limited

E. G. M. Cape and Company, Limited

Cartier, Côté and Piette, Montreal

Century Geophysical Corporation of Canada, Calgary

Charterhouse Canada, Limited

Christensen, MacDonald Construction Ltd., Edmonton

Confederation Life Association

Continental Can Company of Canada, Limited

Continental Life Insurance Company

Cooperative Life Insurance Company, Regina

Crane Canada Limited

H. E. Crowell, Esq., Halifax

Crown Life Insurance Company

Dominion Bridge Company, Limited

Dominion Chain Company, Limited

Dominion Electrohome Industries, Limited

Dominion Forge, Limited

Dominion Foundries and Steel, Limited

Dominion Life Assurance Company

Dominion Stores Limited

Dominion Tar and Chemical Company, Limited

Dow Brewery, Limited

Dow Chemical of Canada, Limited

Dower Brothers, Limited, Edmonton 
Dufresne Engineering Company, Limited, Montreal

Dupont Company of Canada, Limited

Eaton Automotive Products Limited

The T. Eaton Co. Limited

Eckler and Company, Limited

Edmonton Furniture Company

Edmonton Motors, Limited

Edmonton Photo Supply Limited

Emco Limited

Empire Life Insurance Company

Equitable Life Insurance Company of Canada

H.M.E. Evans, Esq., Edmonton

Excelsior Life Insurance Company

Falconbridge Nickel Mines, Limited

Federal Grain Limited, Winnipeg

Federal-Mogul-Bower (Canada) Limited

Federated Co-Operative Limited, Saskatoon

Fiberglas Canada Limited

Fidelity Life Assurance Company

Firestone Tire and Rubber Company of Canada, Limited

Fischer Bearings Manufacturing Limited

General Motors of Canada Limited

B. F. Goodrich Canada Limited

Goodyear Tire and Rubber Company of Canada Limited

Great Atlantic and Pacific Tea Company Limited

Helliwell, Maclachlan and Company, Vancouver

Home Oil Company Limited

Honeywell Controls, Limited

Grant Horsey, Esq. , Toronto

Household Finance Corporation of Canada

Hudson's Bay Company

Hudson Bay Mining and Smelting Co., Limited

Hudson's Bay Oil and Gas Company Limited

Imperial Life Assurance Company of Canada

Imperial Tobacco Company of Canada, Limited

Industrial Acceptance Corporation, Limited

Industrial Life Insurance Company

International Harvester Company of Canada, Limited

Interprovincial Pipe Line Company

Investors Syndicate of Canada Limited

Jenkins' Brothers Limited, Montreal

Johnstone Walker Limited, Edmonton

K. C.S. Limited, Toronto 
Irving Kline Limited, Edmonton

Kraft Foods Limited

La Brasserie Labatt, Limitée

R. W. L. Laidlaw, Esq., Toronto

Lalone, Valois, Lamarre, Valois Associates, Montreal

H. R. Lawson, Esq., Toronto

Law son and Jones Limited, London

Lincoln Electric Company of Canada Limited

Loblaw Groceterias Company, Limited

MacDonald Electric Limited, Kitchener

MacMillan and Bloedel Limited, Vancouver

A.D. Margison and Associates Limited

Marsland Engineering Limited

Massey-Ferguson Limited

Mathews Conveyer Company Ltd., Port Hope

McCabe Grain Company, Limited, Winnipeg

William M. Mercer Limited, Toronto

Metropolitan Life Insurance Company

Metropolitan Stores of Canada Limited

Mining Corporation of Canada, Limited

Minnesota Mining and Manufacturing of Canada Limited

W. and A. Moir, Halifax

Molson's Brewery Limited

H. L. Molstad, Esq., Edmonton

Monarch Life Assurance Company

Monsanto Canada Limited

Montreal City and District Savings Bank

Montreal Engineering Company, Limited

Montreal Life Insurance Company

Moore Corporation, Limited

National Boring and Sounding Inc., Montreal

National Cash Register Company of Canada Limited

National Grain Company Limited, Winnipeg

National Life Assurance Company of Canada

A.D. Nesbitt, Esq., Montreal

Newhouse Wholesale Limited, Edmonton

Niagara Finance Company Limited

The Nickle Foundation

North American Life Assurance Company

Northern Life Assurance Company of Canada

North-West Wholesale Furniture Ltd., Edmonton

Northwestern Utilities, Limited, Edmonton

Norton Company of Canada Limited, Hamilton 
Oldfield, Kirby and Gardner Limited, Winnipeg

Ontario Paper Company Foundation

Osler, Hammond and Nanton Limited, Winnipeg

Otis Elevator Company Limited, Hamilton

Page-Hersey Tubes, Limited

Parker Sportswear Company Limited, Edmonton

Prairie Pacific Distributors Limited, Edmonton

N. M. Paterson and Sons Limited, Winnipeg

Pioneer Grain Company Limited, Winnipeg

Polymer Corporation Limited

K. A. Powell (Canada) Limited, Winnipeg

Les Prévoyants du Canada

Promislow Brothers Limited, Regina

Provincial Bank of Canada

Prudential Assurance Company Limited of England

Pulp and Paper Mill Accessories Limited, Montreal

Quebec North Shore Paper Company

R.C.A. Victor Company, Ltd.

Readers' Digest Association (Canada) Ltd.

Remington Rand Limited

Richard-Wilcox Canadian Company Limited

James Richardson and Sons, Limited

Mrs. Doris E. Rooney, Calgary

Royal Insurance Company Limited

Royal Trust Company

Sandwell and Company Limited

Sangamo Company Limited, Toronto

Searle Grain Company, Limited, Winnipeg

La Sauvegarde compagnie d'assurance sur la vie

L. E. Shaw Limited, Halifax

Sheldon Engineering Limited

Shell Canada Limited

Silverwood Dairies, Limited

Simons, H.A. (International) Ltd.

Simpson Sears Limited and The Robert Simpson

Company Limited

N. Smith Belting Works Limited, Toronto

Socony Mobil Oil of Canada Ltd.

La Solidarité Compagnie d'Assurance

Southam Company Limited

Sovereign Life Assurance Company of Canada

Sparton of Canada Limited, London

Sperry Gyroscope Company of Canada Ltd. 
Spruce Falls Power and Paper Company, Limited Standard Life Assurance Company

Standard Oil Company of British Columbia Limited Sterling Printers, Edmonton

Supertest Petroleum Corporation, Limited, London Surveyer, Nenninger and Chenevert, Montreal

Teck Corporation Limited

Texaco Canada Limited

B. B. Torchinsky and Associates Limited, Saskatoon

Toronto-Dominion Bank

Traders Finance Corporation Limited

Trudeau's Limited, Edmonton

United-Carr Fastener Company of Canada Limited, Hamilton

Underwood McLellan and Associates Limited

United Aircraft of Canada Limited

Vancouver Sun

Weisler's Wholesale Limited, Edmonton

W. C. Wells Construction Co., Ltd. Saskatoon

Westclox Canada Limited, Peterborough

Western Life Assurance Company

Western Plywood Company Limited, Vancouver

Winnipeg Free Press Company Limited

Winspear, Hamilton, Anderson and Company, Edmonton

The Honourable Robert H. Winters, Toronto

Wood, Gundy and Company, Limited

Woodward Stores, Limited, Vancouver

Max Wyman, Esq., University of Alberta, Edmonton

We are indebted also to the Canadian Universities, nearly all of whom contribute to the support of the Canadian Journal of Mathematics and also cooperated with the Congress in providing travel grants to members of their staff to attend the various meetings.

We acknowledge also grants from the Canada Councii and the National Science Foundation to enable invited lecturers from Scotland, Germany and the United States to attend the seminar and congress.

As in past years, our chief support has come from the 
National Research Council and it is to this body that Canadian mathematicians owe so much in the promotion of research.

We must also not overlook the voluntary support and assistance of so many individual members, for without it the Congress would indeed be unable to function. With the growth of the universities and the building of new campuses we can look forward to an ever expanding role in the development of mathematics in Canada.

\section{Executive Director}

L. F.S. Ritcey 
R. D. James (presiding), University of British Columbia

M. Wyman, University of Alberta

H.S. M. Coxeter, University of Toronto

R. L. Jeffery, Acadia University

F. A. Sherk, University of Toronto

\section{CHA IRMAN}

The plan is as follows: Two of the speakers will give short remarks on various a spects of graduate work; then we will call for questions from the floor. Then the two remaining speakers will do the same and there will be more questions and discussion.

Roughly speaking, Professor Wyman will discuss the problem of attracting graduate students; Professor Coxeter will then give a discussion on the difference in graduate training in the United Kingdom versus the United States, together with remarks on the graduate degree. Professors Jeffery and Sherk will talk about the program of research in graduate work.

You will not want to hear too many Chairman's remarks, but I would like to point out the fact that this is a live issue in other countries be sides Canada. A clipping given to me by Professor Divinsky, I think from the New York Times, observes, with regard to teachers in general, that in 1953-54 31 percent had the Doctor's degree, while in 1962- 63 this had dropped to 25 percent. At the same time, the number of teachers holding the Master's degree had gone up a corresponding amount. The director of the research division of the National Education Association states: "In many institutions the only course open to the employing officials will be to lower the standards. "

M. WYMAN, Alberta

As you are aware, I am a last minute replacement as a member of the present panel, a panel that is supposed to discuss various aspects of problems concerned with the graduate education of mathematics students. In this, I am an unwilling 
replacement because these problems have assumed an importance that demands serious study before opinions should be stated and possible solutions advocated.

At a pre-session briefing, I was asked to say a few words about the financial support of graduate education in mathematics in Canada. Since the areas I shall touch do not distinguish mathematics from the other disciplines, it is possible for me to speak about graduate work in general and not mathematics in particular.

Those of us who listened to Professor Kuratowski's lecture this morning could not help but feel that science has attained, in Poland, a position of eminence it has not attained in Canada. People like Professor Kuratowski seem to have convinced the Government of Poland of the scientific needs of a modern society, and science seems to have developed there at an amazing rate during the past twenty years.

Although, during the same period of time, the development of science has come a long way in Canada, we have not yet come close to being self-sufficient in meeting the scientific requirements of our country. We are still leading a parasitic existence in the scientific community of the world.

Even though most universities in Canada are aware of the need for a rapid expansion in graduate work, it is far from clear that the people of Canada are aware of this need, and, more important, it is far from clear that the various Canadian governments are sympathetic to the need for such an expansion.

In a pre-election promise, the present Federal Government indicated a willingness to provide a ten million dollar a year scholarship program to enable high school students to enter universities. Not one word was said about a similar program designed to attract people into graduate work. At a time when universities are being swamped with undergraduate registrations, the emphasis of the above mentioned scholarship program seems to be misplaced.

It is difficult for many people, outside universities, to understand the relatively slow growth in numbers of graduate students at a time when our undergraduate population secms 
to be doubling every four years. Unfortunately, graduate work is the least attractive of the opportunities that are now being offered to B.Sc. graduates. Industry, here and in the United States, often offers positions carrying salaries of $\$ 7,000$ per year to persons who have just received their first university degree. This means that a recent graduate must be prepared to lose an opportunity to earn about $\$ 30,000$ in order to ubtain a Ph. D. degree. Universities must, through some scholarship or assistantship program, attempt to minimize a loss of this magnitude. Clearly, the present value of scholarships and assistantships must double, and we must begin to think of paying fully qualified students sometining like $\$ 5,000$ per year simply to attend a graduate school. Across Canada, such a program would run into millions of dollars just for this one aspect of graduate work. It is indeed our duty to impress on the Canadian governments the need for such a program and that the need is for today, because tomorrow might be too late.

Although a ten-fold increase in the monies now being spent on graduate work is, in my opinion, a prime requisite, money alone will not solve all of the problems we face in the future. Other speakers will discuss problems like mathematical curricula for graduate work and other related aspects of a modern graduate education in mathematics. Aspects of this type are indeed more important than the financial support needed at the present time

The problem of increasing the flow of students into graduate work is one for which no ready solution exists. It will take the best effort of most of the mathematicians in Canada to improve all levels of mathematical training to the point where we can say we are truly self-sufficient in meeting current mathematical needs. Indeed, some of our mathematicians may have to put aside their research and take the time to fight battles in the political arenas of government in order to ensure that graduate work receives the prestige and support it now must have.

\section{H.S.M. COXETER, Toronto}

As you were told in the introduction, I would like to say a word about the comparison between the teaching of mathematics 
in the United States and in Britain. There is an article in the beginning of the latest issue of the Mathematical Gazette by E.B.C. Thornton, undoubtedly an Englishman, pointing out some rather interesting differences. I think it is good for us to look at the comparison, because Canada is in the happy position of being able to make use of the best of both systems and, indeed, I think in many cases has done so. Mr. Thornton says that the background of American education is different in detail, method and philosophy from the English system. Two such instances are seen at once. First, in the United States the course is enjoyed as an entity in itself rather than as a stage in growth. It need not be connected organically with any other course. For example, even in high school, in many programs, a year of algebra is followed by a year of geometry with little connection between the two. Consequently, the aim of the pupil is to complete the course, preferably with a good grade, that is, to reach at all times throughout the year the standard demanded by the teacher and the school. The pupil's attention is focussed fully in each instance on the attaining of a good grade, without any thought that he could take an interest in the subject itself. The emphasis is on short-term achievement rather than on a maturing of insight and understanding. On the other hand, it certainly does ensure intense application by the student. Whether this application comes from the system or is simply an American attribute is immaterial. Doubtless there is interaction. In addition to the general emphasis, the teaching of mathematics differs from the English practice in several respects. The most fundamental of these is the total divorce of mathematics from natural philosophy. Since anyone connected with the teaching of mathematics is essentially pure, there is a great emphasis on rigor. Perhaps it should be pointed out that the organization by courses and the American genius for sustained hard work both lend themselves to the publication of large numbers of packaged course text books. Because of these and because of American habits of study, it is the rule rather than the exception, even among the very many extremely competent instructors, to teach from the book.

I certainly agree with the previous speaker that there is terrific need for competent mathematicians. Industry, of course, can use a large number of them and it is even more important to train competent teachers to look after the future. Therefore I would strongly urge all universities to make sure 
that nobody gets an M. A. degree who is mathematically illiterate. There is the extreme case of the American graduate student who wrote a thesis on Banach spaces and it was found that he had never done any elementary analytical geometry.

For those who wish to work eventually for a $\mathrm{Ph}$. D. , I would recommend allowing an expository thesis to replace an appropriate number of courses in preparation for the M. A. One big advantage of a thesis at this level is that it would provide the university teachers with an opportunity to decide whether the candidate is really suitable to go on to a Ph. D. On the other hand, for an exceptional student who has shown originality already as an undergraduate, I would think that one might allow a part expository and part original $M$. A. the sis to replace perhaps an even greater number of courses. An interesting extreme case of the problem of the gifted student arose some fifty years ago when Professors Hardy and Neville heard about Ramanujan, who had learnt and rediscovered so much by himself in India. I think it was Professor Neville who went all the way to India to fetch him to England; then after he got there the question was how much to leave him to his own devices and how much to bother him with formal instruction on the mathematics that was already known. It seems that an excellent job was done in this case. A good compromise was found. He was allowed to have access to just the right kind of mathematics to help him and, at the same time, not to overburden him. Of course, it was only later seen how important it was to make a wise choice, because his life was so very soon to be cut short.

Now a word about $M$. A. students who go on to the Ph. D. I would suggest that, if the candidate has an $M$. A. of the kind mentioned above, including a thorough mathematical education, he should then be allowed to take as many or as few courses as he pleases, provided his thesis is sufficiently good.

Since the launching of the first Sputnik, there has been in the United States a most laudable improvement in education ( an instance of doing the right thing for the wrong reason) and also a fantastic increase in the availability of grants to encourage research. One cannot escape the feeling that many Americans are doing research because they are well paid for it, whereas the only proper motivation is an irresistable inner urge. One regretable result of the exaggerated encouragement of research 
is the extra burden on the editors and referees of mathematical journals, who have to read vast numbers of new papers which seem, at first sight, acceptable but which are really only making unpromising generalizations or proving uninteresting theorems: the sort of stuff that the late Professor Hardy once referred to as "ugly mathematics".

\section{DISCUSSION}

At this point, time was given for questions and opinions from the floor. The following points were emphasized:

1. Wyman's emphasis on a different magnitude of thinking on the amount of money needed for graduate research was attacked. This led to a discussion of additional ways to attract graduate students, sich as:

(a) The attitude of the teacher during the undergraduate years. He should, for example, encourage the student to check existing literature to find out the way in which a given discovery was made. The study of history of mathematics should be encouraged but not necessarily given formally.

(b) An active interest by mathematicians in pre-university mathematical education.

(c) An increase in the prestige of a career in mathematical research.

2. The close relationship between pure and applied mathematics in England is a good thing, in that it has a broadening effect, according to Coxeter. He pointed out, however, that the difference between the two, as they are taught in England, is small.

3. It was asked if there is any country in which the problem of supply has been solved. Coxeter replied that to the best of our knowledge, Russia is an example. G. Pickert remarked on the situation in Germany. He stated that the supply of university teachers is well up to the demand, but that there is a shortage of high school teachers, which would correspond in this country to a shortage of teachers in the first two years of university. 
4. There was some feeling expressed that the four month summer in Canada is not properly used by the student. The student should be supported during the summer, and prevented from earning money except as a university student.

\section{R. L. JEFFERY, Acadia}

There seemed to be no progress in preparing for this panel until it dawned on me that the difficulty arose because of my trying to separate undergraduate and graduate work. While it is customary to separate these for purposes of bookkeeping, credits, places of residence, etc., the process of learning is independent of them. We take, therefore, as the period of preparation for the Doctorate the last two years of the honours degree and three further years of study and research.

With this settled we put the question as follows: What should be an overall plan of training for men, and women, who are going out, tagged as mathematicians, to represent Canada in the world of Science, Research, Scholarship, and Industry?

In the early part of their undergraduate study students should, for the most part, follow the usual pattern of calculus, differential equations, and the usual introductory work in Modern Algebra and Geometry. At this stage students should go slowly enough to be sure they are on the right track.

Nevertheless, even at this stage there should be a well organized arrangement for acceleration, and acceleration should be emphasized and adequately provided for, both in the undergraduate and graduate years. It will by no means be the case that all good students will want to accelerate. But some will be sure of what they want at an early stage and will be anxious to show that they are capable of a faster than average pace. Besides, to have a group of students in this category lifts the tone of the courses in which they are.

When the introductory work is over, things should begin to tighten up, both for the instructor and the student. Progress in University work is measured in terms of courses; we shall agree that a course means lectures, three hours per week throughout the year, with the associated study and problem work. Every lecture should be a well-prepared performance. It should 
be such that a student would usually need from two to three hours for the necessary reading to clarify any points which were not quite clear during the lecture. In this study time, he should fill in comments in his own ways, so that when he comes back to it months, or years, later he will know what it is all about. He should also have assigned problems and essay work to do. Some problems should be at a reasonable research level and on these much more than the two to three hours will be spent.

In what direction should these courses go, and how many of them should there be? The courses should go in the main direction of the mathematics of the time. At present there should be at least two courses and in some cases three, in each of Modern Algebra, Analysis, Applied Mathematics, Geometry, and Topology and Functional Analysis. There could be some replacements. Statistics and Probability could replace Applied Mathematics; Mathematical Logic and Boolean Algebra could replace Geometry. Statistics and Probability could be at least one of three courses in the Applied group.

In one of the areas from which the courses are taken the student should make an early start on fundamental research leading towards a thesis. There are those of my colleagues whose first reaction to the proposed program will be that it does not allow time for concentrated study and research. It should not be overlooked, however, that the programme is based on the assumption that there is a workable arrangement for acceleration. If such is the case some will be well along with their program by the time they have finished for an honours degree. It will not be unusual to find students on such a program who will have the last year of their three years of graduate work entirely free for independent study and research.

Course is an unfortunate word, and taking courses for courses' sake gets one nowhere. But it is not at all necessary that courses be taken, or given, in this spirit. The atmosphere of a course should be that of getting control of the techniques of operation in a field for the purpose of going further and deeper than the present status of the field. There is no better way to overcome illiteracy and acquire an interest in creative work than by courses taken, and given, in this spirit. If enough effort is put into organizing and conducting a course of two or 
three lectures a week, with essays and problems, some of them research problems at a reasonable level, such a course can be as effective as individual tutorials, in some ways more effective. The program as outlined calls for a high level of organization and preparation on the part of those giving the courses. As is always the case, students will drop out along the way, some with an honours degree, others with a Master's degree; but they will have sound training as far as they go, and will be well-prepared for positions in high school, in Government and industry, and in junior colleges.

\section{F. A. SHERK, Toronto}

As nearly as I can make out, the main reason for my existence on this panel is that I am a fairly recent product of a Canadian graduate school. Therefore, if you will pardon me, I' II base my remarks on my own experience.

I went through the regular Honours Mathematics course at McMaster, stayed on another year for the Master's degree, and then went to Toronto for the $\mathrm{Ph}$. D. The requirement for the Master's degree was three courses and a thesis, and the requirement for the $\mathrm{Ph}$. $\mathrm{D}$. was an additional three courses and a thesis. Thus the number of formal courses taken, counting the undergraduate mathematics courses of third and fourth year, was approximately thirteen. Checking them against Professor Jeffery's list, I find myself up to the mark in Algebra, Geometry, and Analysis, but considerably deficient in the others.

But, in my opinion, the deficiency in course material was made up in the work which went into the two theses. I am very fortunate in having had two very able and understanding thesis directors. Professor Lane, who directed my master's the sis, did what few directors can or will do for their charges; he let me in on his own current research program, spending a great deal of time with me almost every day. The result was that, having had a first hand look at mathematics being created, I emerged from my $M$. A. year with a reasonably good idea of what mathematical research entailed.

Partly because of this experience, it was only about six 
months after I enrolled in the Ph. D. program that I had substantial results in the thesis, even though the topic was entirely different. Here again I had excellent direction, this time from Professor Coxeter. Not content to simply leave his door open for me any time, he took the initiative at least twice a week and dropped in at my office to see how things were going along. I consider the close personal contact, and the enthusiasm for geometry that he instilled in me, to be of much greater value than the course work which I took. And since getting the degree, I have been able to fill in some of the gaps in my knowledge.

So, to sum up what I have to say on this matter, I feel that the program of course work that Professor Jeffery has outlined is rather stiff. Unless the time of graduate study is considerably lengthened, it will leave insufficient time for the student, under the guidance of his thesis director, to delve deeply enough into his major subject, so deeply that it really sinks in, making him a devotee of mathematical research for his whole life. A first hand knowledge of research which precedes a complete program of course work is not out of place. On the contrary, it creates a desire for further background knowledge.

Finally, we are not simply trying to produce scholars. Rather, we need people with enough enthusiasm for their subject that they will go through all the difficulties, disappointments, and hard work that it takes to bring about significant new results.

\section{DISCUSSION}

The ensuing discussion centered around Jeffery's remarks on acceieration. Some cases of acceleration of good students in Canada were mentioned, but there was a general feeling that more must be done in this area.

An alternative proposal of the division of undergraduate honours courses into "fast" and "slow" honours was felt to be inadequate for the needs of the extremely gifted individual 


\section{Abstracts of Contributed Papers}

A non-inductive definition for a regular polytope

H.S. M. Coxeter

University of Toronto

In real Euclidean n-space, a configuration of points [0], lines [1], planes[2], etc., is called a regular polytope if:

(i) It is (in an appropriate sense) connected;

(ii) Whenever a [k-2] and a [k] are incident (the latter containing the former), there are just two [k-1]' s incident with both (for $k=1,2, \ldots, n)$;

(iii) There is a centre from which all the [k]'s are equidistant;

Condition (iii) is clearly equivalent to:

(iii)' The symmetry group contains a reflection $\mathrm{R}_{\mathrm{k}}$ that interchanges the $[k-1]$ ' s mentioned in (ii).

If the space is not real but complex, the number two in (ii) can be replaced by an integer $p_{k} \geq 2$, and the description of $\mathrm{R}_{\mathrm{k}}$ in (iii)' is that it cyclically permutes the $\mathrm{p}_{\mathrm{k}}[\mathrm{k}-1]$ ' $\mathrm{s}$.

Every regular polytope has a Schlafli symbol

$$
p_{1}\left\{q_{1}\right\} p_{2}\left\{q_{2}\right\} \cdots p_{n-1}\left\{q_{n-1}\right\} p_{n} ;
$$

for instance, the ordinary cube is $2\{4\} 2\{3\} 2$. How should $\mathrm{q}_{\mathrm{k}}$ be defined in general? 
An algorithmic solution to a word problem

in group theory

N.S. MendeIsohn

University of Manitoba

Let $G$ be a finitely generated group which is also finitely related. Let $H$ be a subgroup of finite index in $G$ generated by finitely many words in G. Using the Coxeter-Todd and Schreier procedures, the author solves the following:

(1) Find a canonical set of generators $h_{1}, h_{2}, \ldots, h_{u}$ for $\mathrm{H}$;

(2) Find a set of representatives for the right cosets of $H$. Let these be $\mathrm{C}_{1}, \mathrm{C}_{2}, \mathrm{C}_{3}, \ldots, \mathrm{C}_{\mathrm{t}}$;

(3) Given a word $W$ in G, find a way of expressing $W$ in the form $W=T\left(h_{1}, h_{2}, \ldots, h_{u}\right) C_{1}$ where $\mathrm{T}\left(\mathrm{h}_{1}, \mathrm{~h}_{2}, \ldots, \mathrm{h}_{\mathrm{u}}\right)$ is a word in $h_{1}, h_{2}, \ldots, h_{u}$, $h_{1}^{-1}, h_{2}^{-1}, \ldots, h_{u}^{-1}$. 
A generalization of Taylor series and Newton interpolation of entire functions

D. Sato

University of Saskatchewan, Regina

Let $f(Z)$ be an entire function and $\left\{z_{i}\right\}$ be an indefinite sequence of complex numbers (not necessarily distinct) with

$$
\lim _{i \rightarrow \infty}\left|z_{i}\right|<\infty \text {. }
$$

Then, there exists a rearrangement $\left\{Z_{j}^{\prime}\right\}$ of the sequence $\left\{z_{i}\right\}$ by which $f(Z)$ can be expanded as a generalized Taylor series form

$$
f(z)=\sum_{n=0}^{\infty} a_{n}\left(z-z_{i}^{\prime}\right) \ldots\left(z-z_{n}^{\prime}\right) .
$$

If $\left\{z_{i}\right\}$ is bounded then we can let $\left\{z_{j}\right\}=\left\{z_{i}\right\}$. The condition (1) is necessary for an unbounded sequence. Taking for $\left\{Z_{i}\right\}$ an enumeration of all algebraic numbers in which each appears infinitely often, we have a transcendental entire function which, together with all its higher derivatives, assumes algebraic values at all algebraic points. 
Regular polygons over Galois fields

B. M. Puttaswamaiah and G. de B. Robinson

University of Toronto

Crowe has recently considered this problem (Amer. Math. Monthly 68 (1961), 762-765 and Proc. Amer. Math. Soc. 13 (1962), 500-502), but has restricted his attention to unitary groups of transformations in the finite plane. The result of this restriction is to so simplify the situation that nothing of great interest seems to emerge. We show here why this restriction should not be made and explain how the problem is closely related to modular representation theory of groups. 


\title{
Boolean geometry of p-rings
}

\author{
R. A. Melter \\ University of Rhode Island
}

A p-ring is a ring $R$ (with identity) in which $p X=0$ and $\mathrm{X}^{\mathrm{P}}=\mathrm{X}$ for all $\mathrm{X} \in \mathrm{R}$ and some prime $\mathrm{p}$. If there is associated with every ordered pair (X, g) of elements of $R$ the idempotent $\mathrm{d}(\mathrm{X}, \mathrm{g})=(\mathrm{X}-\mathrm{g})^{\mathrm{p}-1}, \mathrm{R}$ becomes a Boolean Metric space with distance algebra, the Boolean algebra of idempotents of $R$. Various geometrical properties of such spaces (p-spaces) are discussed in this paper. In particular:

(1) A necessary and sufficient condition is obtained in order that a subset of a p-space form a metric basis;

(2) Congruence indices $p+1$ for a $p$-space with respect to the class of all Boolean metric spaces are determined;

(3) A metric characterization of p-spaces is described;

(4) The group of motions of a p-space is analyzed and it is shown that every motion can be expressed as a product of a finite number of involutions;

(5) A theory of analytic geometry in $\mathrm{p}$-spaces is introduced. 
I N V I T E D

L E C T U R E S 
